\title{
ПОРІВНЯЛЬНА ХАРАКТЕРИСТИКА ЕФЕКТИВНОСТІ ВІЛЬНОЇ ТА НАНОФОРМИ ПРЕПАРАТУ БЕТАМЕТАЗОНУ ПРИ КОНТАКТНОМУ НІКЕЛЕВОМУ ДЕРМАТИТІ
}

\author{
๑І. І. Худан-Цільо, О. О. Шевчук, М. М. Корда \\ ДВНЗ «Тернопільський державний медичний університет імені І. Я. Горбачевського МОз України»
}

РЕЗЮМЕ. Топічні глюкокортикостероїди (ТГКС) $є$ препаратами вибору для місцевого лікування контактних алергійних дерматитів (КД) завдяки наявності виражених протизапальних та протиалергійних властивостей. Однак вони не запобігають розвитку рецидивів та викликають ряд побічних реакцій.

Метою нашого дослідження стало вивчення ефективності наноінкапсульованої та вільної форм бетаметазону дипропіонату на моделі контактного нікелевого алергійного дерматиту.

Матеріал і методи. Дослідження проводили на 40 щурах-самцях, яких було рандомізовано на чотири групи (n=10): 1 - інтактні тварини; 2 - тварини з експериментальним КД; 3 - щури з КД, яким для корекції застосовували бетаметазону дипропіонат у вільній формі (КД + бетаметазон); 4 - щури з КД, яким наносили наноінкапсульовану форму бетаметазону (КД+нанобетаметазон). Полімерні хітозанові наночастинки готували за методикою Hussain Z. et al. (2013). Видимі зміни на шкірі КД оцінювали за візуальною шкалою та товщиною шкірної складки, також вивчали інтенсивність оксидативного та нітрооксидативного стресу.

Результати. Аплікація 5 \% нікелю сульфату спричиняла видимі виражені зміни шкіри і розвиток оксидативного та нітрооксидативного стресу зі зростанням вмісту продуктів ліпопероксидації й одночасним зниженням показників антиоксидантного захисту. Застосування вільної форми ТГКС бетаметазону супроводжувалося видимим покращенням стану шкірних покривів, товщина шкірної складки зменшувалася на 32,1 \%. Знижувалася інтенсивність оксидативного та нітрооксидативного стресу з позитивними змінами всіх досліджуваних показників (спостерігали достовірне зниження вмісту ТБК-активних продуктів, NOx та інших з нормалізацією показників ферментативної та неферментативної ланок захисту клітин - СОД, каталази, відновленого глутатіону).

Аплікація наноінкапсульованого ТГКС перевищувала застосування вільної його форми як за візуальними даними, так і за інтенсивністю впливу на досліджувані показники, що свідчить про перспективність подальшого вивчення та впровадження у клінічну практику нанотехнологій для лікування контактних алергійних дерматитів.

КЛючОВІ СлОВА: контактний алергійний дерматит; нанотехнології; оксидативний стрес; лікування; бетаметазону дипропіонат.

Вступ. Сьогодні спостерігається прогресивний ріст захворюваності та поширеності дерматозів, що пов'язано з широким використанням все більшої кількості різноманітних хімічних сполук у побуті, косметології та парфумерії, зростанням рівня забрудненості навколишнього середовища [1-3]. За даними Міністерства охорони здоров'я, найбільш розповсюдженим серед алергодерматозів в Україні $\epsilon$ контактний дерматит (КД). Показник захворюваності на цю патологію зріс з 717,5 до 779 на 100000 населення. Показники, що перевищують середні по Україні, реєструвалися в таких областях як Волинська $(1043,7)$, Черкаська $(983,8)$, Чернівецька $(940,2)$, Хмельницька $(920,0)$, Луганська $(837,5)$, Запорізька $(803,2)$, м. Севастополь $(954,1)$, АР Крим $(1053,0)$, та у Харківському регіоні $(1125,4)[4]$.

Частота розвитку КД сягає 15-20\% серед дорослого населення $[4,5]$ та значно знижує якість життя, негативно впливає на соціальну адаптацію та професійну діяльність $[3,6]$. Серед чинників, які можуть провокувати розвиток хвороби - лікарські засоби, які застосовують місцево; косметика, парфумерія; деякі рослини; латекс та інші резинові вироби; синтетичні клеї, предмети побутової хімії тощо $[7,8]$. Найчастіше пусковими чин- никами слугують метали - кобальт, хром, нікель, ванадій та інші $[8,9]$. Частота розвитку алергійних реакцій сповільненого типу зросла також і з більш широким впровадженням та використанням металічних імплантів у ортопедії, кардіології, гінекології, стоматології [10]. Топічні глюкокортикостероїди (ТГКС) $є$ препаратами вибору для місцевого лікування КД завдяки наявності виражених протизапальних та протиалергійних властивостей [2]. Однак вони не запобігають розвитку рецидивів, не забезпечують контроль за тяжкістю перебігу захворювання та викликають ряд побічних реакцій, як місцевих, так і системних $[11,12]$.

Відомо, що розвиток оксидативного стресу $\epsilon$ невід' ємним компонентом запальних та алергічних захворювань шкіри [13-15]. Також важлива роль відводиться нітрооксидативному стресові у розвитку та хронізації КД. Враховуючи вищесказане, головним завданням науковців $\epsilon$ максимальне зниження ризику виникнення побічних ефектів топічних стероїдів за умови збереження та посилення їхньої ефективності.

Метою нашого дослідження стало вивчення ефективності наноінкапсульованої та вільної форм бетаметазону дипропіонату на моделі контактного нікелевого алергійного дерматиту та їх впливу 
Огляди літератури, оригінальні дослідження, погляд на проблему

на розвиток оксидативного та нітрооксидативного стресу.

Робота виконана в рамках НДР 0112 U000542 «Біохімічні механізми токсичності наночастинок різної природи та інших антропогенних і біогенних токсикантів і біологічних систем» та 0116 U003353 «Біохімічні механізми порушень метаболізму за умов надходження до організму токсикантів різного ґенезу».

Матеріал і методи дослідження. Досліди проведено на 40 статевозрілих білих щурах-самцях масою 180-220 г, яких методом сліпої вибірки було рандомізовано на чотири групи (n=10): 1 - інтактні тварини; 2 - тварини з експериментальним контактним нікелевим дерматитом (КД); 3 - щури з КД, яким для корекції застосовували бетаметазону дипропіонат у вільній формі (КД + бетаметазон); 4 - щури з КД, яким наносили наноінкапсульовану форму бетаметазону (КД + нано-бетаметазон). При проведенні досліджень дотримувалися міжнародних правил та принципів «Європейської конвенціїпро захистхребетнихтварин, яківикористовуються для експериментів та з іншою науковою метою» (Страсбург, 1986) і Закону України «Про захист тварин від жорстокого поводження» (№ 1759-VI від 15.12.2009) та Директиви Європейського Союзу 2010/10/63 EU щодо експериментів на тваринах.

Контактний нікелевий дерматит моделювали шляхом щоденного нанесення протягом 12 днів на ретельно вистрижену ділянку шкіри (площею $3 \times 3$ см) щурів 4 г водного ланоліну, що містив 5 \% NiSO4.

Для досліджень використовували бетаметазону дипропіонат (Sigma, Aldrich, USA). Наночастинки з інкапсульованим бетаметазону дипропіонатом готували за методикою Hussain Z. et al. [16]. Полімерні хітозанові наночастинки готували шляхом іонного «зшивання" хітозану з триполіфосфатом натрію (ТРP). Розчин хітозану (0,2 \%) готували на 1 \% розчині оцтової кислоти ( $\mathrm{pH}=5)$ і інкубували, перемішуючи з бетаметазону дипропіонатам 1 мг/мл в 30:70 суміші етанол/вода протягом 30 хв при кімнатній температурі. До 25 мл інкубаційної суміші по краплях додавали 10 мл 0,1% водного розчину ТРP. Суміш постійно перемішували за допомогою магнітної мішалки (700 о6/хв). Отримані наночастинки відцентрифуговували (28000 об/хв.) протягом 30 хв і потім ліофілізували при $-40{ }^{\circ} \mathrm{C}$ протягом 24 год. Розмір наночастинок визначали за допомогою морфометричної програми ВідеоТест - 5.0, KAAPA ImageBase, за даними електронної мікроскопії їх розмір коливався від 40 до 100 нм.

Бетаметазон та його нанокапсульовану форму у вигляді суміші з водним ланоліном після формування контактного нікелевого дерматиту наносили протягом 7 днів на уражену ділянку шкіри 2 рази на добу. Інтенсивність розвитку дерматиту оцінювали візуально за виразністю запальної реакції шкіри в балах (0 - відсутність видимої реакції, 1 - слабка еритема, 2 - чітка еритема, 3 чітка еритема з ущільненням, 4 - еритема з явищами геморагії, вираженою інфільтрацією та серозно-геморагічними кірками з виразками) та за динамікою товщини шкірної складки [17].

Тварин виводили з експерименту шляхом декапітації під тіопенталовим наркозом на 20 добу експерименту. Визначали кількість лейкоцитів та ШОЕ як додаткові показники інтенсивності запального процесу. Проводили визначення у гомогенатах печінки (отримували за допомогою гомогенізатора Heidolph Silent Crusher M) та сироватці крові піддослідних тварин продуктів вільнорадикального окиснення: ТБК-активних продуктів (ТБК-П) (Андреева Л. И. та ін., 1988); показників антиоксидантного захисту: активності супероксиддисмутази (СОД) (Чевари С. та ін., 1985), каталази (Королюк М. А. та ін., 1988), вмісту відновленого глутатіону (G-SH) (Ellman G.L., 1959), загальної антиокислювальної активності сироватки крові (ЗАА) (Stock J. et al., 1974). Показники активності нітрооксидативного стресу визначали шляхом визначення вмісту стабільних метаболітів оксиду азоту NOx (нітрит-аніону, NO2- та нітрат-аніону $\mathrm{NO}^{-}$) (Green L. C. et al., 1982) та сумарної активності NO синтази (Ridnour L. et al., 2000).

Отриманий цифровий матеріал був оброблений методом варіаційної статистики з використанням критерію Манна-Уітні та однофакторного дисперсійного аналізу (ANOVA). Розраховували середні арифметичні величини (М), похибки середніх арифметичних (m), коефіцієнти варіації, а також середні квадратичні відхилення. Зміни вважали достовірними при р $\leq 0,05$. У таблицях рівень значимості вказували тільки для достовірних результатів. Для розрахунків використовували комп' ютерну програму Microsoft Excel XP (USA) та Statsoft STATISTICA.

Результати й обговорення. Відомо, що найбільша частота серед зареєстрованих КД припадає на нікель-індуковані через нікельвмісні виро6и, нікельовані прикраси та пірсінг [18]. Американським товариством контактних дерматитів (American Contact Dermatitis Society (ACDS) цей метал було названо «контактним алергеном року».

До моменту застосування лікувальних чинників було констатовано наявність видимих змін шкірних покривів у експериментальних групах тварин. У місцях нанесення сульфату нікелю розвивалася виражена запальна реакція, що супроводжувалася гіперемією та геморагіями, вираженою інфільтрацією шкіри; розвивалися виразки з 
Огляди літератури, оригінальні дослідження, погляд на проблему

геморагічними кірками. Значний набряк тканини

слідних тварин, порівняно з інтактними щурами, у призводив до потовщення шкірної складки у до- 2,4 раза на 12 добу експерименту (табл. 1).

Таблиця 1. Вплив препаратів бетаметазону на вираженість контактного нікелевого дерматиту в щурів $(M \pm m, n=10)$

\begin{tabular}{|l|c|c|c|}
\hline \multirow{2}{*}{ Показник } & Групи тварин & \multicolumn{2}{|c|}{ Термін спостереження } \\
\cline { 2 - 3 } & & 12 доба & 20 доба \\
\hline \multirow{2}{*}{$\begin{array}{l}\text { Інтенсивність ураження } \\
\text { шкіри, бали }\end{array}$} & Інтактні тварини & $0,0 \pm 0$ & $0,0 \pm 0$ \\
\cline { 2 - 4 } & КД & $3,12 \pm 0,38^{*}$ & $2,68 \pm 0,43^{*}$ \\
\cline { 2 - 4 } & КД + бетаметазон & $3,06 \pm 0,29^{*}$ & $1,82 \pm 0,18^{*}$ \\
\hline \multirow{2}{*}{$\begin{array}{l}\text { Товщина шкірної } \\
\text { складки, мм }\end{array}$} & КД + нанобетаметазон & $3,18 \pm 0,42^{*}$ & $1,17 \pm 0,24^{*},{ }^{* *}, \#$ \\
\cline { 2 - 4 } & Інтактні тварини & $1,65 \pm 0,07$ & $1,71 \pm 0,05$ \\
\cline { 2 - 4 } & КД & $4,02 \pm 0,29^{*}$ & $3,78 \pm 0,19^{*}$ \\
\cline { 2 - 4 } & КД + бетаметазон & $3,98 \pm 0,30^{*}$ & $2,68 \pm 0,12^{*},{ }^{* *}$ \\
\hline
\end{tabular}

Примітки: тут і далі:

1. * вірогідно щодо значень інтактного контролю, $\mathrm{p}<0,05$;

2. ** вірогідно щодо значень контрольної патології, $\mathrm{p}<0,05$;

3. \# вірогідно щодо значень групи, яка отримувала вільну форму бетаметазону, p < 0,05.

На 20 добу експерименту інтенсивність ураження шкіри незначно знижувалася у щурів і без застосування лікувальних чинників. Однак все ще у третини тварин були зафіксовані виразки та геморагічні кірки, виражена еритема та набряк, показник товщини шкірної складки мав незначну тенденцію до зниження.

Застосування вільної форми бетаметазону супроводжувалося вираженим видимим покращенням. На 7 добу щоденних аплікацій не було обширних виражених виразок та геморагічних кірок на уражених ділянках шкіри, також загоювалися і ерозії. Явища гіперемії були значно менше виражені, зберігався набряк. Вираженість шкірних проявів у балах була меншою на $32,1 \%$, порівняно 3 контрольною патологією на 20 добу, та достовірно відрізнялася (зменшення показника на 40,5 \%) порівняно зі станом шкіри тварин на 12 добу експерименту. Товщина шкірної складки зменшувалася на 29,1 \% порівняно з нелікованим КД, та на 32,7 \% - порівняно зі станом до корекції.

Застосування наноінкапсульованої форми бетаметазону супроводжувалося більш вираженими позитивними змінами з боку шкіри. За візуальною бальною шкалою інтенсивністьураження шкірних покривів зменшувалася на 56,3 \% порівняно з контрольною патологією, та на 35,7 \% - порівняно з тваринами, яким наносили звичайний бетаметазон.

Показник товщини шкірної складки у тварин, яким наносили на уражену шкіру наноформу бетаметазону, був нижчим на 43,9\%, порівняно з нелікованими тваринами; та на 20,9 \% порівняно з групою тварин, яким наносили місцево вільну форму ГКС.

Розвиток контактного дерматиту супроводжувався підвищенням вмісту лейкоцитів у периферійній крові щурів у 1,77 раза (табл. 2) та зростанням ШОЕ у 1,84 раза, що свідчить про розвиток системної запальної реакції.

Таблиця 2. Вплив препаратів бетаметазону на вираженість контактного нікелевого дерматиту в щурів $(M \pm m, n=10)$

\begin{tabular}{|c|c|c|c|}
\hline \multirow{2}{*}{ Показник } & Групи тварин & \multicolumn{2}{|c|}{ Термін спостереження } \\
\cline { 2 - 3 } & & 12 доба & 20 доба \\
\hline Лейкоцити, 109/л & Інтактні тварини & $6,28 \pm 0,29$ & $6,24 \pm 0,32$ \\
\cline { 2 - 4 } & КД & $11,12 \pm 0,38^{*}$ & $9,68 \pm 0,33^{*}$ \\
\cline { 2 - 4 } & КД + бетаметазон & $10,96 \pm 0,29^{*}$ & $8,47 \pm 0,28^{*},{ }^{* *}$ \\
\cline { 2 - 4 } & КД + нанобетаметазон & $11,18 \pm 0,42^{*}$ & $7,17 \pm 0,24^{*},{ }^{* *}, \#$ \\
\hline \multirow{3}{*}{ ШОЕ, Мм/хв } & Інтактні тварини & $4,25 \pm 0,27$ & $4,71 \pm 0,25$ \\
\cline { 2 - 4 } & КД & $7,82 \pm 0,39 *$ & $6,98 \pm 0,49^{*}$ \\
\cline { 2 - 4 } & КД + бетаметазон & $7,98 \pm 0,30^{*}$ & $5,68 \pm 0,32^{*},{ }^{* *}$ \\
\cline { 2 - 4 } & КД + нанобетаметазон & $8,04 \pm 0,38^{*}$ & $5,12 \pm 0,20^{*},{ }^{* *}$ \\
\hline
\end{tabular}

Застосування вільного бетаметазону зменшувало рівень лейкоцитів на 12,5 \%, а його наноінкапсульованої форми - на 26,1%, порівняно 3 контрольною патологією; швидкість осідання еритроцитів була нижчою на 18,6 \% та на 26,6 \% відповідно. 
Огляди літератури, оригінальні дослідження, погляд на проблему

При цьому вміст лейкоцитів при застосуванні наноформи ГКС був на 15,4 \% нижчим, ніж при застосуванні його вільної форми, а показники ШОЕ мали чітку тенденцію до подальшого зниження.
Шкірні прояви контактного нікелевого дерматиту супроводжувалися розвитком оксидативного та нітрооксидативного стресу, про що свідчили досліджувані показники сироватки крові та гомогенату печінки (табл. 3, 4).

Таблиця 3. Порівняльна активність різних форм бетаметазону щодо показників оксидативного стресу $(\mathrm{M} \pm \mathrm{m}, \mathrm{n}=10)$

\begin{tabular}{|c|c|c|c|c|}
\hline \multirow{2}{*}{ Показник } & \multicolumn{4}{|c|}{ Група } \\
\hline & інтактні тварини & КД & КД + бетаметазон & КД + нанобетаметазон \\
\hline \multicolumn{5}{|c|}{ Кров } \\
\hline ТБК-П, мкмоль/л & $0,83 \pm 0,04$ & $1,49 \pm 0,08 *$ & $1,09 \pm 0,04 * *$ & $0,94 \pm 0,02 * *, \#$ \\
\hline $\begin{array}{l}\text { Каталаза, } \\
\text { мкат/л }\end{array}$ & $8,61 \pm 0,27$ & $14,86 \pm 0,11^{*}$ & $11,54 \pm 0,14$ ** & $10,02 \pm 0,19 * *, \#$ \\
\hline $\begin{array}{l}\text { СОД, } \\
\text { ум. од./л }\end{array}$ & $4,43 \pm 0,08$ & $2,79 \pm 0,17^{*}$ & $3,38 \pm 0,26 * *$ & $4,12 \pm 0,18 * *, \#$ \\
\hline $3 A A, \%$ & $53,33 \pm 4,08$ & $38,09 \pm 2,65^{*}$ & $48,27 \pm 3,34 * *$ & $49,36 \pm 4,09 * *$ \\
\hline \multicolumn{5}{|c|}{ Печінка } \\
\hline ТБК-П, мкмоль/кг & $6,72 \pm 0,26$ & $9,21 \pm 0,31 *$ & $7,27 \pm 0,18 * *$ & $7,02 \pm 0,16^{* *}$ \\
\hline $\begin{array}{l}\text { Каталаза, } \\
\text { мкат/кг }\end{array}$ & $7,99 \pm 0,08$ & $15,66 \pm 0,45^{*}$ & $10,11 \pm 0,15 * *$ & $9,68 \pm 0,09 * *$ \\
\hline $\begin{array}{l}\text { СОД, } \\
\text { ум. од./кг }\end{array}$ & $5,07 \pm 0,01$ & $2,84 \pm 0,12 *$ & $3,98 \pm 0,11 * *$ & $4,31 \pm 0,16 * *$ \\
\hline $\begin{array}{l}\text { G-SH, } \\
\text { ммоль/кг }\end{array}$ & $2,37 \pm 0,05$ & $1,16 \pm 0,09 *$ & $1,78 \pm 0,08 * *$ & $1,92 \pm 0,08 * *$ \\
\hline
\end{tabular}

Таблиця 4. Активність NO-синтази та вміст нітратів і нітритів $\left(\mathrm{NO}_{\mathrm{x}}\right)$ у щурів з $\mathrm{KД}(\mathrm{M} \pm \mathrm{m}, \mathrm{n}=10)$

\begin{tabular}{|c|c|c|c|c|}
\hline \multirow{2}{*}{ Показник } & \multicolumn{4}{|c|}{ Група } \\
\hline & інтактні тварини & КД & КД + бетаметазон & КД + нанобетаметазон \\
\hline \multicolumn{5}{|c|}{ Кров } \\
\hline $\begin{array}{l}\mathrm{NO}_{\text {х, }} \\
\text { ммоль/л }\end{array}$ & $3,72 \pm 0,31$ & $5,95 \pm 0,49 *$ & $4,77 \pm 0,24 * *$ & $4,58 \pm 0,25 * *$ \\
\hline \multicolumn{5}{|c|}{ Печінка } \\
\hline $\begin{array}{l}\text { NO-синтаза, } \\
\text { нмоль/мг білка хв }\end{array}$ & $3,08 \pm 0,26$ & $6,01 \pm 0,31 *$ & $4,64 \pm 0,18 * *$ & $4,29 \pm 0,16^{* *}$ \\
\hline
\end{tabular}

У крові та печінці зростав рівень вторинних продуктів перекисного окиснення ліпідів (ПОЛ): вміст ТБК-П був вищим на 79,5 та 37,5 \% відповідно. Одночасно спостерігалася активація ферменту каталази на 72,6 та 96,0 \%, що супроводжувалося зниженням активності СОД на 44,0 та 37,0 \% відповідно у сироватці крові та тканинах печінки. Рівень відновленого глутатіону при цьому був нижчим на 51,05 \%, порівняно з інтактними тваринами. Загальна антиоксидна активність сироватки крові при розвитку КД знижувалася у 1,4 раза. Під впливом вільного бетаметазону показник зростав на $26,7 \%$; його наноформи - на $29,6 \%$.

Топічне застосування такого потужного протизапального стероїдного середника як бетаметазону дипропіонат (належить до сильних топічних глюкокортикостероїдів) приводило до зниження інтенсивності зсувів у про-/ антиоксидантній системі, викликаних аплікацією нікелю сульфату. Спостерігали зниження рівня продуктів ПОЛ у сироватці крові та печінці: вміст ТБК-П був нижчим на 26,8 та 21,1 \% відповідно.

Спостерігали активацію ендогенних факторів антирадикального та антиперекисного захисту. Активність каталази була нижчою на 22,3 та 35,4 \% у сироватці крові та тканинах печінки відповідно, порівняно з контрольною патологією. Одночасно зростала активність СОД у печінці та сироватці крові на 40,1 та 21,1 \% відповідно. 3ростав рівень G-SH, він був вищим на 53,4 \%.

Аплікація наноінкапсульованого бетаметазону дипропінату мала більш виражений регулювальний вплив на показники надмірних процесів ПОЛ. Вміст ТБК-П у печінці був нижчим на 23,8 \%, порівняно з тваринами з КД, які не отримували жодної корекції. Вміст ТБК-П у сироватці крові зменшувався на 36,9 та 13,8 \%, порівняно з контрольною патологією та групою тварин, які отримували звичайну форму ГКС, відповідно. 
Огляди літератури, оригінальні дослідження, погляд на проблему

Водночас спостерігали більш виражені позитивні зміни з боку антиоксидантної системи організму. Активність каталази у печінці та сироватці крові була нижчою на 38,2 та 32,6 \%, порівняно 3 контрольною патологією. Водночас цей показник у сироватці крові був достовірно нижчим, порівняно з групою тварин, які отримували вільний бетаметазон, на 13,2\%.

Активність СОД при застосуванні наноінкапсульованого топічного стероїдного протизапального засобу зростала на 47,7 \% у сироватці крові та на 51,8 \% у печінці. Водночас ці показники були достовірно вищими на 21,9 \% у крові та мали виражену тенденцію до зростання у тканинах печінки.

Рівень відновленого глутатіону був вищим у 1,7 раза (на 65,5 \%) порівняно з контрольною патологією, та простежувалася тенденція до його зростання порівняно з показниками групи тварин, які отримували звичайну форму бетаметазону.

Зростання вмісту нітратів і нітритів на тлі розвитку КД у периферійній крові на 59,9 \% свідчить про розвиток нітрооксидативного стресу. При цьому сумарна активність NO-синтази зростала на $95,1 \%$. Застосування вільного бетаметазону знижувало обидва показники на 19,8 та 21,0 \% відповідно. Активність NO-синтази знижувалася на 22,8\%.

Наноінкапсульвана форма ТГКС викликала зниження NOx на $23,0 \%$, активність NO-синтази знижувалася на $28,6 \%$.

Терапією вибору КД $\epsilon$ місцеве лікування уражених ділянок ГКС, завдяки наявності у них виражених протизапальних, протисвербіжних та інших властивостей [19]. Основні їх фармакодинамічні ефекти включають антизапальну, протишокову, антитоксичну, протиалергічну та імуносупресивну дії. Механізм протизапальної дії універсальний за рахунок пригнічення генів резидентних та мігруючих клітин шкіри, які беруть участь у запаленні. Внаслідок цього зникає свербіж, зменшуються набряк, гіперемія та ексудація [20, 21]. Відомо, що ТГКС впливають на структури і епідермісу, і дерми. Після проникнення всередину клітини вони реагують з білковими рецепторами, утворюючи комплекс «стероїд-рецептор», який потрапляє у

\section{ЛITEPATУРA}

1. Кузнецова Ю. Контактный дерматит как результат агрессии окружающей среды. Чем лечить? / Ю. Кузнецова // Российский аллергологический журнал. 2015. - № 5. - C. 76-81.

2. Guideline contact dermatitis / J. Brasch, D. Becker, W. Aberer [et al.] // Allergo Journal International. - 2014. Vol. 24, Issue 4. - P. 12-138.

3. Hand eczema severity and quality of life: A crosssectional, multicentre study of hand eczema patients / T. Agner, K. E. Andersen, F. M. Brandao [et al.] // Contact Dermatitis. - 2008. - Vol. 59, No. 1. - P. 43-47. ядерні структури клітини та зв' язується з ДНК. Потім відбувається транскрипція месенджерної РНК (mRNA), через яку ГКС можуть стимулювати або пригнічувати синтез специфічних білків. Також відомо, що стероїди стимулюють синтез ліпокортину, який пригнічує активність фосфоліпази А2, що відповідає за метаболізм арахідонової кислоти та $\epsilon$ попередником простаноїдів і лейкотрієнів [22].

Наноінкапсулювання активних лікарських засобів змінює їх фармакологічну активність та завдяки цьому значно посилює основні ефекти на організм.

Висновки. 1. Аплікація 5 \% сульфату нікелю протягом 12 днів призводить до розвитку виражених ознак контактного дерматиту та пошкодження структур шкіри у досліджуваних тварин, що підтверджується візуальними змінами та потовщенням шкірної складки у 2,4 раза, а також супроводжується розвитком оксидативного та нітрооксидативного стресу зі зростанням рівня показників продуктів ПОЛ та ослабленням ланок ендогенного антиоксидантного захисту (компенсаторно зростає активність каталази та знижуються показники активності СОД і вмісту відновленого глутатіону).

2. Застосування вільної форми сильного топічного глюкокортикостероїду бетаметазону супроводжується зниженням інтенсивності ураження, як за візуальними ознаками, так і достовірним зниженням інтенсивності ПОЛ та активацією показників антиоксидантного захисту.

Наноінкапсульована форма бетаметазону вірогідно більш інтенсивно покращує стан уражених шкірних покривів досліджуваних тварин, в тому числі і в порівнянні з групою щурів, котрі отримували вільну форму бетаметазону: достовірно кращими були показники як і ПОЛ, так і антиоксидантного захисту у сироватці крові та тканинах печінки.

4. Отримані результати дослідження свідчать по перспективність подальшого вивчення та впровадження у клінічну практику наноінкапсульованих форм топічних глюкокортикостероїдів для лікування контактних дерматитів.

4. Солошенко Е. М. Динаміка розповсюдженості та захворюваності на поширені дерматози в Україні і Харківському регіоні за останні 10 років / Е. М. Солошенко, В. Волкославська, О. Л. Гутнєв // Дерматологія та венерологія. - 2014. - Т. 63, № 1. - С. 69-78.

5. The burden of skin disease in the United States // H. W. Lim, S. A. B. Collins, J. S. Resneck [et al.] // J. Am. Acad. Dermatol. - 2017. - Vol. 76, No. 5. - P. 958-972.

6. Патоморфологические изменения кожи у больных аллергическим контактным дерматитом при воздействии низкомолекулярных аллергенов (гаптенов) / 
Огляди літератури, оригінальні дослідження, погляд на пр О. Уханова, Т. Шишалова, А. Копылов // Медицинский вестник Северного Кавказа. - 2012. - Т. 26, № 2. С. 71-73.

7. American Contact Dermatitis Society Core Allergen Series: 2017 Update / P. C. Schalock, C. A. Dunnick, S. Nedorost [et al.] // Dermatitis. - 2017. - No. 28 (2). - P. 141-143.

8. Чурилов А. Никель в биосредах здоровых женщин репродуктивного возраста / А. Чурилов, Е. Соловьёва //Український медичний альманах. - 2011. - Т. 14, № 3. - С. 194-195.

9. Evaluation and pattern of nickel dermatitis in patients with allergic contact dermatitis / M. Khan, Z. Rani, M. Ahmed [et al.] // Journal of Pakistan Association of Dermatology. - 2016. - Vol. 15, No. 2. - P. 136-139.

10. Investigation of contact allergy to dental metals in 206 patients / U. Raap, M. Stiesch, H. Reh [et al.] // Contact Dermatitis. - 2009. - Vol. 60, No. 6. - P. 339-343.

11. Prevention and management of glucocorticoid-induced side effects: A comprehensive review: Gastrointestinal and endocrinologic side effects / A. Caplan, N. Fett, M. Rosenbach [et al.] // Journal of the American Academy of Dermatology. - 2017. - Vol. 76, No 2. - P. 11-16.

12. A systematic review of topical corticosteroid withdrawal ("steroid addiction") in patients with atopic dermatitis and other dermatoses / T. Hajar, Y. A. Leshem, J. M. Hanifin [et al.] // Journal of the American Academy of Dermatology. - 2015. - Vol. 72, No. 3. - P. 541-549.

13. Okayama Y. Oxidative stress in allergic and inflammatory skin diseases / Y. Okayama // Curr. Drug Target Inflammation Allergy. - 2005. - Vol. 4, No. 4. - P. 517-519.

14. The roles of reactive oxygen species produced by contact allergens and irritants in monocyte-derived den- dritic cells / M.-G. Lee, D. Byamba, T. Gyun Kim [et al.] // Annals of Dermatology. - 2010. - Vol. 22, No. 3. - P. 269-278.

15. Schieber M. ROS function in redox signaling and oxidative stress / M. Schieber, N. Chandel // Current Biology. - 2014. - Vol. 24, No. 10. - P. 453-462.

16. Self-assembled polymeric nanoparticles for percutaneous co-delivery of hydrocortisone/hydroxytyrosol: an ex vivo and in vivo study using an NC/Nga mouse model / Z. Hussain, H. Katas, M. C. Mohd Amin [et al.] // Int. J. Pharm. - 2013. - Vol. 444, Issue 1-2. - P. 109-119.

17. Волковой В. А. Вивчення лікувальної ефективності нової мазі з ліпофільним комплексом із кори осики "Тремулін" за умов неалергічного контактного дерматиту в щурів / В. А. Волковой, І. В. Кучинська, Т. І. Тюпка // Фармакологія та лікар. токсикологія. 2010. - № 6. - C. 7-12.

18. Molecular mechanisms of nickel allergy / M. Saito, R. Arakaki, A. Yamada [et al.] // International Journal of Molecular Sciences. - 2016. - Vol. 17, No. 2. - P. 202.

19. Guideline contact dermatitis / J. Brasch, D. Becker, W. Aberer [et al.] // Allergo Journal International. - 2014. Vol. 23, No. 4. - P. 30-43.

20. Лусс Л. В. Современные проблемы диагностики и терапии аллергического контактного дерматита / Л. В. Лусс // Дерматология. - 2009. - No. 2. - Р. 63-67.

21. Usatine R. P. Diagnosis and management of contact dermatitis // R. P. Usatine, M. Riojas // Am. Fam. Physician. - 2010. - Vol. 82, No. 3. - P. 249-55.

22. Jacob S. E. Pharmacotherapy for allergic contact dermatitis / S. E. Jacob, M. P. Castanedo-Tardan // Expert Opin. Pharmacother. - 2007. - Vol. 8, No. 16. P. 2757-2774.

\section{REFERENCES}

1. Kuznetsova, Yu. (2015). Kontaktnyy dermatit kak rezultat agressii okruzhayushchey sredy. Chem lechit? [Contact dermatitis as a result of environmental aggression. What do we treat with?]. Rossiyskiy allergologicheskiy zhurnal - Russian Allergological Journal, 5, 76-81 [in Russian].

2. Brasch, J., Becker, D., Aberer, W., Bircher, A., Kränke, B., Jung, K. et al. (2014). Guideline contact dermatitis. Allergo Journal International, 23 (4), 126-138.

3. Agner, T., Andersen, K.E., Brandao, F.M., Bruynzeel, D.P., Bruze, M., Frosch, P. et al. (2008). Hand eczema severity and quality of life: a cross-sectional, multicentre study of hand eczema patients. Contact Dermatitis, 59 (1), 43-47.

4. Soloshenko, E.M., Volkoslavskaya, V.M., Gutnev, O.L. (2014). Dynamika rozpovsiudzhenosti ta zakhvoriuvanosti na poshyreni dermatozy v Ukraini i Kharkivskomu rehioni za ostanni 10 rokiv [The dynamics of the prevalence and incidence of common dermatoses in Ukraine and the Kharkiv region over the past 10 years]. Dermatolohiia ta venerolohiia - Dermatology and Venereology, (1), 68-77 [in Ukrainian].

5. Lim, H.W., Collins, S.A., Resneck, J.S., Bolognia, J.L., Hodge, J.A., Rohrer, T.A. et al. (2017). The burden of skin disease in the United States. Journal of the American Academy of Dermatology, 76 (5), 958-972.

6. Ukhanova, O.P., Shishalova, T.N., Kopylov, A.V., Getman, R.A., Lysogora, L.V. (2012). Patomorfologiches- kiye izmeneniya kozhi u bolnykh allergicheskim kontaktnym dermatitom pri vozdeystvii nizkomolekulyarnykh allergenov (gaptenov) [Pathomorphological changes in skin in patients with allergic contact dermatitis when exposed to low molecular weight allergens (haptens)]. Meditsinskiy vestnik Severnogo Kavkaza - Medical Gazette of the North Caucasus, 26 (2) [in Russian].

7. Schalock, P.C., Dunnick, C.A., Nedorost, S., Brod, B., Warshaw, E., Mowad, C. (2017). American Contact Dermatitis Society Core Allergen Series: 2017 Update. Dermatitis, 28(2), 141-143.

8. Churilov, A.V., Solovyova, E.A., Kozlov, K.P. (2011). Nikel v biosredakh zdorovykh zhenshchin reproduktivnogo vozrasta [Nickel in the biomedia of healthy women of reproductive age]. Ukrainskyi medychnyi almanakh - Ukrainian Medical Almanac, 14 (3), 194-195 [in Russian].

9. Khan, M.S., Rani, Z., Ahmed, M.L., Hussain, I., Kazmi, A.H. (2016). Evaluation and pattern of nickel dermatitis in patients with allergic contact dermatitis. Journal of Pakistan Association of Dermatology, 15 (2), 136-139.

10. Raap, U., Stiesch, M., Reh, H., Kapp, A., Werfel, T. (2009). Investigation of contact allergy to dental metals in 206 patients. , 60 (6), 339-343.

11. Caplan, A., Fett, N., Rosenbach, M., Werth, V.P., \& Micheletti, R.G. (2017). Prevention and management of glucocorticoid-induced side effects: A comprehensive 
Огляди літератури, оригінальні дослідження, погляд на проблему

review: Infectious complications and vaccination recommendations. Journal of the American Academy of Dermatology, 76 (2), 191-198.

12. Hajar, T., Leshem, Y.A., Hanifin, J.M., Nedorost, S.T., Lio, P.A., Paller, A.S. et al. (2015). A systematic review of topical corticosteroid withdrawal ("steroid addiction") in patients with atopic dermatitis and other dermatoses. Journal of the American Academy of Dermatology, 72 (3), 541-549.

13. Okayama, Y. (2005). Oxidative stress in allergic and inflammatory skin diseases. Current Drug Targets-Inflammation \& Allergy, 4 (4), 517-519.

14. Byamba, D., Kim, T.G., Kim, D.H., Je, J.H., Lee, M.G. (2010). The roles of reactive oxygen species produced by contact allergens and irritants in monocyte-derived dendritic cells. Annals of Dermatology, 22 (3), 269-278.

15. Schieber, M., \& Chandel, N.S. (2014). ROS function in redox signaling and oxidative stress. Current Biology, 24 (10), 453-R462.

16. Hussain, Z., Katas, H., Amin, M.C.I.M., Kumolosasi, E., Buang, F., \& Sahudin, S. (2013). Self-assembled polymeric nanoparticles for percutaneous co-delivery of hydrocortisone/hydroxytyrosol: an ex vivo and in vivo study using an $\mathrm{NC} / \mathrm{Nga}$ mouse model. International Journal of Pharmaceutics, 444 (1), 109-119.

17. Volkovoy, V.A., Kuchynska, I.V., Tyupka, T.I. (2010). Vyvchennia likuvalnoi efektyvnosti novoi mazi z lipofilnym kompleksom iz kory osyky "Tremulin" za umov nealerhichnoho kontaktnoho dermatytu $v$ shchuriv [Study of the therapeutic efficacy of a new ointment with a lipophilic complex from the bark of the "Tremulin" aspen under non-allergic contact dermatitis in rats]. Farmakolohiia ta likarska toksykolohiia - Pharmacology and Drug Toxicology, 6, 7-12 [in Ukrainian].

18. Saito, M., Arakaki, R., Yamada, A., Tsunematsu, T., Kudo, Y., \& Ishimaru, N. (2016). Molecular mechanisms of nickel allergy. International Journal of Molecular Sciences, 17 (2), 202.

19. Brasch, J., Becker, D., Aberer, W., Bircher, A., Kränke, B., Jung, K. et al. (2014). Guideline contact dermatitis. Allergo Journal International, 23 (4), 126-138.

20. Luss, L.V. (2009). Sovremennyye problemy diagnostiki i terapii allergicheskogo kontaktnogo dermatita [Modern problems of diagnostics and therapy of allergic contact dermatitis]. Dermatologiya - Dermatology, (2), 6367 [in Ukrainian].

21. Usatine, R.P., \& Riojas, M. (2010). Diagnosis and management of contact dermatitis. American Family Physician, 82 (3), 249-255.

22. Jacob, S.E., \& Castanedo-Tardan, M.P. (2007). Pharmacotherapy for allergic contact dermatitis. Expert Opinion on Pharmacotherapy, 8 (16), 2757-2774.

\section{СРАВНИТЕЛЬНАЯ ХАРАКТЕРИСТИКА ЭФФЕКТИВНОСТИ СВОБОДНОЙ И НАНОФОРМЫ ПРЕПАРАТА БЕТАМЕТАЗОНА ПРИ КОНТАКТНОМ НИКЕЛЕВОМ ДЕРМАТИТЕ}

\section{๑И. И. Худан-Цильо, О. О. Шевчук, М. М. Корда}

ГВУЗ «Тернопольский государственный медицинский университет имени И. Я. Горбачевского МЗ Украины», г. Тернополь

РЕЗЮМЕ. Топические глюкокортикостероиды (ТГКС) являются препаратами выбора для местного лечения контактныхаллергическихдерматитов (КД) благодаря наличиюпротивовоспалительныхипротивоаллергических эффектов. Однако они не предупреждают развитие рецидивов и вызывают ряд побочных эффектов.

Целью нашего исследования стало изучение эффективности наноинкапсулированной и свободной форм бетаметазона дипропионата на модели контактного никелевого аллергического дерматита.

Материал и методы. Исследования проводились на 40 крысах-самцах, рандомизированных на четыре группы (n=10): 1 - интактные животные; 2 - с экспериментальным КД; 3 - крысы с КД, которым для коррекции использовали бетаметазона дипропионат в свободной форме (КД+бетаметазон); 4 - крысы с КД, которым наносили наноинкапсулированный бетаметазон (КД+нанобетаметазон). Полимерные хитозановые наночастицы готовили по методике Hussain Z. et al. (2013). Изменения на коже оценивали по визуальной шкале и по толщине кожной складки, также изучали интенсивность оксидативного и нитрооксидативного стресса.

Результаты. Аппликация 5 \% никеля сульфата вызывает выраженные изменения кожи с развитием оксидативного и нитрооксидативного стресса и увеличением уровня продуктов липопероксидации с одновременным снижением показателей антиоксидантной защиты. Применение свободной формы ТГКС бетаметазона сопровождалось видимым улучшением состояния кожных покровов, толщина кожной складки уменьшалась на 32,1 \%. Снижалась интенсивность оксидативного и нитрооксидативного стресса с позитивными изменениями всех исследуемых показателей (достоверное снижение содержания ТБК-активных продуктов, NOx и других, с нормализацией показателей ферментативного и неферментативного звеньев защиты клеток - СОД, каталазы, восстановленного глутатиона).

Аппликация наноинкапсулированного ТГКС превышала применение его свободой формы как по визуальным данным, так и по влиянию на показатели оксидативного и нитрооксидативного стресса. Это свидетельствует о перспективности дальнейшего исследования и внедрения в клиническую практику нанотехнологий для лечения контактных аллергических дерматитов.

КЛЮЧЕВЫЕ СЛОВА: контактный аллергический дерматит; нанотехнологии; оксидативный стресс; лечение, бетаметазона дипропионат. 


\section{Horbachevsky Ternopil State Medical University}

SUMMARY. Topical glucocorticoids (TGCSs) are the drugs of choice for local treatment of contact allergic dermatitis (CD) because of potent anti-inflammatory and anti-allergic properties. But they do not prevent the relapses and have some serious side effects.

The aim of the study is an investigation of efficacy of free and nano-encapsulated betamethasone in contact nickel dermatitis.

Materials and Methods. Experiment was carried out on 35 white inbred rats, which were divided into 4 groups. 1st group - intact rats; 2 nd - rats with contact nickel dermatitis (CD); 3rd - rats which got free form of Betamethasone (CD + Betamethasone); 4th - group which got nano-capsulated Betamethasone (CD + nano- Betamethasone). Visual scale and thickness of skin fold were used for estimation of visible changes, also the intensity of oxidative and nitrooxidative stress was studied.

Results and Discussion. Application of $5 \%$ nickel sulfate caused prominent damage to skin and rising of oxidative and nitrooxidative stress with increased levels of lipoperoxidation products and simultaneous suppression of antioxidant defense indices. Free betamethasone improved the visible changes of the skin; the thickness of skin fold was less by $32.1 \%$. Intensity of oxidative and nitrooxidative stress decreased with positive dynamics of all indices (significant decreasing of TBARS-products, NOx was observed with normalization of activity and content of enzyme and non-enzyme chains of sell protect - SOD, catalase, restored glutathione).

Application of nano-encapsulated Betamethasone was more efficient that it's free form for visual signs and influence on other indices. It means that further investigation and clinical implementation of nanotechnologies is prospective direction of contact dermatitis treatment.

KEY WORDS: contact allergic dermatitis; nanotechnology; oxidative stress; treatment, betamethasone dipropionate. 